\title{
LEGAL STATUS OF RESERVOIRS: RUSSIAN AND FOREIGN APPROACHES TO THEIR CREATION AND OPERATION
}

\author{
Marina Vakula \\ Assoc. Prof., RUDN University, Russia, vakula2004@yandex.ru
}

\begin{abstract}
The global function of reservoirs in the modern hydro-climatic system is the conservation of water on the mainland. The multidimensional nature of the reservoir functionality is enormous: guaranteed water supply to industrial enterprises and settlements; hydroelectric (HPP) and pumped storage power plants (PSP); flood control; irrigation of agricultural land; increasing the volume and quality of ecosystem services; use in fishery; water transport development.
\end{abstract}

Meantime, large reservoirs are also characterized by negative environmental effects: land flooding, coastal processing, waterlogging of settlements, salinization, acidification of the landscape of the river floodplain in the downstream, changes in the meteorological regime of the adjacent territory, regional activation of the earth's crust movements.

This article analyzes the problems of legal regulation of the processes of the creation and operation of reservoirs. The author investigates the legal status of reservoirs as a human-made water body referring to the legal status of hydraulic structures, entailing the actual formation of reservoirs. The approaches to public administration and the protection of reservoirs used in Russia and other countries are compared. It also provides a brief overview of the legal loopholes in Russia.

The purpose of this publication is to identify the shortcomings and contradictions in the legal status of reservoirs in the Russian Federation, which are both a source of drinking water supply, an anthropogenic water body, and water transport.

The goal of this study will be achieved by performing the following tasks:

- The study of foreign and Russian approaches to water management;

- The analysis of the applicability of the results of the experience of other states to the existing approaches in Russia to determine the legal status of reservoirs and hydraulic structures;

- Development of proposals for changing the Russian regulatory framework governing the creation and operation of reservoirs and hydraulic structures.

The methodological base of the research is constituted by such general scientific methods as dialectical and systemic research methods, analysis, synthesis, induction, deduction, analogy, and alike, and such specific scientific methods as historical and legal research, comparative legal research, formal legal, structuralfunctional and statistical methods. The study is based on the results of studies conducted by Russian and foreign lawyers, ecologists, hydrologists, as well as economists related to the research topic.

The results of the study can be used for effective water management of the creation and operation of reservoirs in the legal aspect for countries with similar problems in the field of water management.

Keywords: hydraulic structures, reservoir, ecological functions of reservoirs, risks of negative impact on the environment. 


\section{INTRODUCTION}

In Russia, hydropower plants are the most important tool for ensuring the reliability and safety of the country's unified energy system, since they provide up to $90 \%$ of its capacity reserve. Hydro technical structures (hydroelectric power stations - hereinafter referred to as HPP) play a key role in protecting settlements and industrial facilities from floods. Reservoirs of hydroelectric power plants provide over a third of the volume of domestic water supply in Russia, over a quarter of the volume of irrigation and watering. Regulation of river flow with their help allows you to create deep-water transport routes. [2]

At the same time, the Water Strategy of Russia [17] noted a shortage of water resources in certain regions of the country, caused, inter alia, by the limited regulatory capacities of reservoirs to meet the resource needs of the population, industry, agriculture, fisheries, inland water transport, as well as the insufficient integrated approach to water use resources in some water plots.

At the same time, the integrated approach implies the solution of such diverse problems as ensuring technical and environmental safety, preventing the negative impact of water, reducing the level of negative impact on the reservoir itself as a water body (including biological water resources), as well as on other environmental components in the adjacent territories - forests, green spaces, soils, wildlife.

\section{METHODOLOGY}

The methodological basis of this work was the study of the main approaches to the legal regulation of the creation and operation of reservoirs used in the Russian Federation, as well as practiced abroad, and the development of recommendations on the possibility of introducing foreign approaches in the Russian Federation. The analysis of interdisciplinary regulation of reservoirs in the status of a source of drinking water supply, an anthropogenic water body shows the need for further development of the integrated use and protection of water bodies as the basis for the implementation of water management measures and the protection of water bodies located within the boundaries of river basins.

\section{RESULTS}

\subsection{The Legal Regulation and Development of Water Reservoirs in the Russian Federation}

To achieve the goals of sustainable development, the basic principles of water legislation provide for basin approaches to the process of water management: basin districts (Art. 28 of the Water Code of the RF), [18] basin councils (Art. 29 of the Water Code of the RF), schemes for the integrated use and protection of water bodies (Art. 33 of the Water Code of the RF). Meanwhile, the Water Strategy of the Russian Federation for the period until 2020 provided for the transformation of basin councils into key governing bodies that will make responsible decisions in the field of water management.

The river basin is defined by the Water Code of the Russian Federation as a territory, the surface runoff of water from which through connected water bodies and streams is carried out into the sea or lake. Basin districts are the main management unit in the field of use and protection of water bodies and consist of river basins and associated underground water bodies and seas.

For each basin district, it is proposed to create its basin council (part 1 of Art. 29 of the Water Code of the $\mathrm{RF}$ ), which should develop recommendations in the field of use and protection of water bodies that should be taken into account when developing schemes for the integrated use and protection of water bodies. The recommendations of the basin councils are taken into account when developing schemes for the integrated use and protection of water bodies. They are also sent to the relevant federal executive bodies, executive bodies of the constituent entities of the Russian Federation and local self-government bodies that exercise authority in the use and protection of water bodies.

The basin councils include representatives of the federal executive bodies authorized by the Government of the Russian Federation, government bodies of the constituent entities of the Russian Federation, local governments, as well as representatives of water consumers, public associations, and indigenous communities of the North, Siberia and the Far East of the Russian Federation. The basin council is created by the decision of the Federal Agency for Water Resources for 5 years. [3] Based on the above norms, basin councils do not play a significant role in the use and protection of water bodies, since they only develop recommendations.

The next level of planning can be mentioned in the development of schemes for the integrated use and protection of water bodies - SKIOVO (Engl. SIUPWB). Under Art. 33 of the Water Code of the Russian Federation, schemes for the integrated use and protection of water bodies include systematized materials on 
the state of water bodies and their use and are the basis for water management measures and measures for the protection of water bodies.

When developing SKIOVO (SIUPWB), the forecasts of the socio-economic development of the Russian Federation for the long, medium and short term, by sectors of the economy, regions, and concerning transboundary water bodies, are taken into account, as well as the provisions of international treaties of the Russian Federation in the field of sharing and protection of transboundary water bodies.

The schemes are mandatory for state authorities and local self-government bodies, and are implemented by planning and implementing on their basis all water management measures and measures to protect water bodies aimed at satisfying the actual and future demand for water resources, systematic reduction of anthropogenic impact on water bodies ensuring the rational use and protection of water bodies, as well as preventing the negative impact of water.

It should be noted that the implementation of water management measures and measures for the protection of water bodies provided by SKIOVO (SIUPWB), is impossible without taking into account the specifics of the operation of the reservoirs forming the hydraulic structures.

The legislation defines hydraulic structures as dams, hydroelectric power plants, structures designed to protect against floods, destruction of the banks and bottom of reservoirs, rivers, as well as other structures, buildings, devices and other objects designed to use water resources and prevent the negative effects of water and liquid waste, except for facilities of centralized hot water supply systems, cold water supply and (or) water disposal. [9]

According to state standards, the reservoir is defined as an artificial reservoir formed by a water support structure on a watercourse to store water and regulate flow. [10]

It should be noted that from the legal regime of the dam and the reservoir, the only object is the drainage [8] systems defined by the legislation on land reclamation as systems of interconnected hydraulic and other structures and devices (channels, collectors, pipelines, reservoirs, spillovers, dams, pumping stations, water intakes, other structures and devices on reclaimed land).

The legal regime of the hydroelectric power station and the legal regime of the reservoir formed in connection with its construction are determined by different branches of legislation. The owner of a hydraulic engineering structure may be, following the provisions of the Law "On the Safety of Hydraulic Engineering Structures", the Russian Federation, an entity of the Russian Federation, a municipality, an individual or a legal entity, regardless of its legal form. At the same time, the RF Water Code establishes federal ownership of water bodies. The Russian Federation delegates to the authorities of the constituent entities of the Russian Federation the protection of water bodies; to prevent the negative impact of water and eliminate its consequences. The exception is water bodies that are fully located in the territories of one constituent entity of the Russian Federation, and the use of their water resources is carried out to ensure drinking and domestic water supply to two or more constituent entities of the Russian Federation.

At the same time, the costs of eliminating the consequences of the harmful effects of water, as well as compensation for the damage caused are made by the constituent entities of the Russian Federation at the expense of subventions from the federal budget.

The Water Code of the Russian Federation secured the transfer of certain powers of the Russian Federation in the field of water relations to state authorities of the constituent entities of the Russian Federation, in fact expanding their competence even further (Art. 26 of the Water Code of the RF).

However, powers are partially transferred to state authorities of the constituent entities of the Russian Federation. Of the three main "levers of control" - regulatory, financial and administrative - the regional authorities fully enough receive only one - administrative (they form the system of governing bodies, organize the transfer of water bodies for consumption, and ensure their protection). The other two levers remain mainly at the federal level.

The main part of normative legal acts of the water sector is approved by the federal government or authorized federal executive bodies. The main funding goes through the federal budget: almost all water income goes there and from there, funds are allocated for the implementation of the transferred water powers in the form of targeted subventions.

On the other hand, the responsibility for what happens with water bodies lies almost entirely with the executive bodies of the constituent entities of the Russian Federation - they are responsible for the protection, organization of water use and, in general, for the final result of the state management of water bodies. In turn, local governments also receive a share of responsibility for ensuring the timely protection of 
territories from the negative impact of water.

Therefore, it is necessary to find a compromise between the costs and benefits of several participants in water relations, which sometimes pursue completely different goals. For example, it is important for the owner of a large hydroelectric power station (HPP), which is a part of a unified energy system, to fulfill the planned tasks for generating electricity, and flood protection measures and the operation of the reservoir will no longer concern him because the dam and the reservoir are not a unified object. At the same time, regional authorities, first of all, are concerned about the security problems of settlements, the preservation of a favorable environment for the population and ensuring the sustainable functioning of the industrial complex of the region. At the same time, at the federal level of management, the task should be solved much wider, because often reservoirs are located on the territory of several constituent entities of the Russian Federation and are designed to provide them with water resources, but also to prevent negative consequences for water users at other reservoirs of this water body (cascade of reservoirs) above and below the watercourse.

One of the most important conditions for the proper operation of reservoirs is to ensure a normal retaining water level, which is achieved "under normal operating conditions of a hydraulic structure." [11] However, the establishment and subsequent fluctuations of the normal retaining level of the reservoir (including the coastline of the reservoir) will inevitably affect the urban planning of the territories, because there are flooding zones, flooding of the territories, which are displayed in the documents of territorial planning, urban zoning, and planning documentation. In this regard, regional authorities, local governments bear significant expenses both in the framework of measures to protect against the negative impact of water and because of the reduction in the value of the real estate and restrictions on urban development in unfavorable territories. At the same time, a previously existing ecosystem on these lands is changing and this requires additional financing of compensatory measures.

\subsection{Legal Regulation of the Creation and Operation of Reservoirs Abroad}

Canadian water law (Water Act 1985, etc.) addresses general issues of water resources management, use, and protection, including through the signing of federal-provincial agreements. Since the 1960s in Canada about a hundred federal and provincial agreements were signed on, inter alia, water quality, and its monitoring.

As in the United States, the entities of the federation - the provinces, adopt their water laws and play a large role in environmental management. It is at the expense of the provincial budgets that flood control and irrigation reservoirs are maintained and operated. [20]

The following example can be cited from Australia's water management organization. In 1987, the MurrayDarling Basin Agreement was signed. Its participants are the federal government, the governments of New South Wales, Victoria, South Australia.

The purpose of the Basin Agreement is to ensure equitable, efficient and sustainable use of the waters, lands and other natural resources of the basin. This is the landscape approach, which to some extent will help to overcome the shortcomings of customary law in Australia. [19]

The modern water legislation of France (the 1992 law) has created a flexible water management system based on the involvement of all participants in the water sector to the development and implementation of water policy for common good.

The Czech Republic has Act No. 305/2000 on "Reservoirs" in force. The legislator of this Eastern European country provides for such a participant in water relations as the organization, managing the reservoirs. [13]

For example, in the Federal Republic of Germany, in Rhine-North-Westfalen land, for about a century the river associations Ruhrverband and Emshergenossenschaft have been working, responsible for certain parts of the Rhine river basin. The fact is that water scarcity and increasing anthropogenic pressure in the Ruhr required industrial water users to act together.

Ruhrverband consists of representatives (Association), executive (Executive Committee) and oversight (Supervisory Board) bodies. Ruhrverband takes over the construction and operation of reservoirs, water treatment plants, sewage, and stormwater treatment plants. For this, the named organization charges a fee from water users and municipalities.

At the same time, as a rule, there are no such long and productive traditions in the CIS countries. The exceptions are in the countries of traditional irrigation agriculture and sustainable water scarcity. According to Articles 96 - 102 of the Water Code of the Republic of Kazakhstan 2003, the status of irrigation and drainage condominium, which is necessary for the economic use of water bodies and water facilities, is regulated in great detail. [7] For many years now, the Law of the Republic of Tajikistan "On the Association of Water 
Users" has been in force, which aims to lay the legal foundations for the organization, management, and activities of the water user association. [12] These non-profit organizations are designed to operate and maintain irrigation systems in the public interest. Moreover, according to Art. 2 of the Law, the irrigation system includes a lot: hydraulic structures, canals, reservoirs, pipelines, pumping and drainage wells, other infrastructure related to water management.

Using its sovereignty, the state assigns the water fund mainly to public property. However, due to the federal structure of the state, a question on the ratio of federal property to the property of the entities of the federation arises and is legally resolved.

In some federations (Brazil, USA), state ownership of surface and groundwater is very common. Under Art. 20 , and 26 of the Constitution of the Republic of Brazil, the Union owns lakes, rivers and all water flows on the lands of its possessions, as well as water flows washing more than one state, meanwhile the surface and groundwater flowing to the surface and appearing on it - is classified as state property. At the same time, the waters resulting from public works (obviously, reservoirs) carried out by the Union under the law belong to the same Union. Thus, the results of a large hydraulic engineering construction are fixed in federal ownership. We also note that in the USA, states historically own groundwater, inland seawater, etc. [16]

Currently, the concession agreement [6] is one of the characteristic forms of public-private partnerships in the field of water management. Concession water use [15] has been intensively developed abroad since the end of the 19th - beginning of the 20th century. For example, in the USA, Switzerland, Norway, and Italy, during hydraulic engineering and hydropower construction, a concessionary procedure for water use have developed. [4]

To ensure the proper quality of drinking water, which is mainly taken from surface sources, the Norwegian Parliament adopted in 1985 a drinking water supply development plan. The legislator puts forward requirements for increased protection of reservoirs and watersheds when carrying out economic activities fraught with pollution. It must be admitted that this policy is beginning to bear fruit. The capital of the Kingdom - Oslo is supplied with $70 \%$ of the drinking water from the lake, located $6 \mathrm{~km}$ from the city.

The Directive of the European Parliament and the Council on Water Policy [5] provides for the integrated work of institutions and committees within river basins. The river basin as a control unit includes both surface and groundwaters. For individual basins, management plans and water improvement programs are required. If the river basin is transboundary, then the EU member states draw up a single management plan for the entire river basin, or at least its separate part.

In leading foreign countries, the system of protection of water bodies has an effective focus on the introduction of new technologies that meet the challenges of nature conservation. This system is characterized by programmatic approaches, involving all "levels of power" in it, actively applying economic incentives [14] through tax and credit benefits. In foreign countries, regardless of water policy, the main bodies of water management are state bodies, which usually belong to the type of ministries. They rely on a system of state and municipal bodies, water users associations, etc. [1]

To a certain extent, the self-organization of water users is a sign of civil society inherent in the West. The states of the European Union and North America have followed the path of water user associations for a long time. For them, this is the usual form of self-organization of participants in water relations, which is consistent with deep-rooted and almost continuous traditions.

\section{DISCUSSIONS}

The formation and maintenance of a cascade of reservoirs lead to serious environmental problems not only in Russia but also in other countries. To ensure the legal unity of water and land, the legislator does not have to increase the land component in the construction of a water body as an object of ownership.

Russia's water strategy focuses not so much on huge financial investments in the water sector, but rather on measures to improve the quality of management (development of water management documentation and information, and analytical support). These include the development and approval of schemes for the integrated use and protection of water bodies (in the Soviet period they were approved but rarely), the development of new and updating the existing rules for the use of reservoirs based on the water and the hydraulic structure register.

The use of land, water, and other natural resources within the framework of the ecosystem of a large water body must be coordinated, avoiding harm to nature and not forgetting the right of people to relax by the water. For such mutual coordination, the relevant legal norms, including water legislation, are needed.

First of all, these are diverse and long-existing public coastal stripes (it is forbidden to privatize them), water 
protection zones, coastal protection zones or sanitary districts. In every possible way reducing the anthropogenic load, these regimes (except for the regime of the coastal protective strip) are designed to preserve the natural state of the land, forest, and other vegetation on it to preserve the self-purification of waters, in which various elements of the aquatic ecosystem are involved, including the bottom and coast.

The listed legal regimes allow authorized bodies (in foreign legislation - water administrators) to take measures for the safety of water-retaining structures that form a reservoir, to ensure the safety of residents and economic facilities in the coastal zone of the reservoir and the underlying section of the watercourse.

For their part, business entities are obliged to ensure that the conditions for the use of part of the reservoir's water received from the authorized body when issuing decisions on water use or when concluding water use agreements with them are met. In this case, it is necessary to find a mutually acceptable way to resolve the conflict of interests of water users of a particular reservoir, which is part of the cascade (for example, the Volga cascade) and reservoirs located in areas above and below the watercourse, and to ensure that public interests are respected throughout the cascade of reservoirs.

In Russia, the unification of interests occurs solely by the will of the "water administrator" in the framework of the legislation of the Russian Federation. As a result, the process is aggravated by the disunity of the owners of large hydraulic structures and regional and municipal authorities, which are designed to ensure the sustainable development of the territory adjacent to the reservoir and prevent the negative impact of water. Therefore, it is difficult to advance projects, including the construction of large hydraulic structures, which will affect not only the territories directly adjacent to the reservoir but also relatively remote territories.

In this case, the experience of foreign countries in terms of self-organization of water users for providing water to industrial enterprises and settlements as a whole, developing hydropower and water transport, as well as preventing the negative impact of water and providing the population with high-quality ecosystem services could be extremely useful for Russia. Besides, it seems appropriate to adopt a separate normative legal act aimed at regulating water relations during the construction and operation of reservoirs.

\section{Acknowledgment}

The publication has been prepared with the financial support of the «RUDN University Program 5-100».

\section{REFERENCE LIST}

1. Bogolyubov, S.A., Sivakov, D.O. (2009) Water legislation in questions and answers: Scientific and practical manual / IZISP. Moscow, pp. 269 - 271.

2. Conclusion of the Committee on Natural Resources, Environmental Management and Ecology of 09.09.2010 "On the draft of Federal Law No. 385728-5" Technical Regulations "On the safety of hydraulic structures of power plants"

3. Decree of the Government of the Russian Federation of November 30, 2006 No. 727 "On the procedure for the creation and activities of basin councils"

4. Dembo, L.I. (1948) The main problems of the Soviet water legislation. Leningrad, pp. 19 - 33

5. Directive 2000/60 / EC of the European Parliament and of the Council of 23 October 2000 on water policy

6. Drozdov, I. (2006) On the legal nature of the concession agreement. Economy and Law. No. 6. pp. 48 57.

7. Edition of the Parliament of the Republic of Kazakhstan. Astana, 2003. pp. 174 - 177.

8. Federal Law of 10.01.1996 No. 4-FZ "On Land Reclamation"

9. Federal law of July 21,1997, No. 117-FZ "On the safety of hydraulic structures"

10. GOST 19179-73. State standard of the USSR. Hydrology of terrestrial area. Terms and definitions (entered into force by the Decree of the USSR State Standard of 10.29.1973 No. 2394)

11. GOST 19185-73 "Hydraulic Engineering. Basic Concepts", approved by Decree of the USSR State Standard of October 31, 1973 No. 2410

12. Law of the Republic of Tajikistan of November 15, 2006 No. 243 "On the Association of Water Users" 
13. Ownership of land in Russia and the EU: legal problems: proceedings of articles (2009) / Ed. I.A. Ikonitskaya. Moscow, pp. 249-250.

14. Sivakov, D.O. (2012) Trends in the legal regulation of water management: monograph. Moscow, IZiSP, Jurisprudence, $352 \mathrm{p}$.

15. Sosna, S.A. (2002) Concession agreement: theory and practice. Moscow.

16. The Constitution of the States of America: In 3 vol. (2006) / Ed. by Academician T.Ya. Khabrieva Moscow, IziSP, Vol. 3: South America. pp. 121 - 302.

17. The order of the Government of the Russian Federation of August 27, 2009 No. 1235-r (as amended on April 17, 2012) "On the approval of the Water Strategy of the Russian Federation for the period until 2020"

18. The Water Code of the Russian Federation dated 03.06.2006 No. 74-FZ

19. Vildyaev, V. (2005) Features of the management of water bodies abroad. Natural Resources Gazette. No. 31 (278).

20. Vystorobets, E.A. (2006) Environmental law - motivation in international cooperation. Moscow. 